\title{
The “Relational Self”: Philosophical-Religious Reflections in Anthropology and Personalism
}

\section{[“Relacne Ja": filozoficko-nabozenske uvahy $\mathrm{v}$ oblasti antropologie a personalizmu]}

\author{
Michal Valco - Peter Sturak
}

DOI: 10.18355/XL.2018.11.01XL.24

\begin{abstract}
Countering the forces of depersonalization and dehumanization which ran rampant in the course of the $20^{\text {th }}$ century, the personalist movement (Mounier, Maritain, etc.) has made a solid attempt to lay the foundations for protecting human dignity, reorienting modern philosophical endeavors to focus again on basic questions of anthropology. While appreciating the motives and emphases of personalism in philosophy, the authors of this article argue in favor of the relational aspect in establishing human personhood, one's dignity and inalienable rights. This notion has been developed by philosophers/theologians of the Eastern/Byzantine intellectual tradition. In addition, we argue that Soren Kierkegaard relational personalist existentialism has the potential to help us understand that human person's dignity is inalienable and indisputable, for in their necessary albeit often unrecognized relatedness to transcendence, human persons have a transcendent source and destiny.
\end{abstract}

Key words: Relational personalism, human person, personalism, anthropology, Kierkegaard, Tillich

\section{Anotácia}

V snahe vysporiadat' sa s vplyvmi depersonalizácie a dehumanizácie, ktoré sa rozmohli v priebehu 20. storočia, sa hnutie personalizmu (Mounier, Maritain, atd'.) pokúsilo položit' základ pre ochranu l'udskej dôstojnosti. Tento ciel' sa snažilo docielit' (čiastočne úspešne) tým, že preorientuje úsilie moderného filozofického diskurzu tak, aby sa znovu primárne zaoberal základnými otázkami antropológie. Autori tejto štúdie na jednej strane oceňujú motívy a aj konkrétne dôrazy personalizmu vo filozofii, no na druhej strane chcú novým spôsobom zdôraznit' relačný (vzt'ahový) aspekt pri utváraní l’udskej osoby, jej dôstojnosti a neodňatel'ných práv. Túto myšlienku rozvíjali filozofi/teológovia východnej/byzantskej intelektuálnej tradície. Ďalej tvrdíme, že relačno-personalistický existencializmus Sorena Kierkegaarda má potenciál pomôct' nám pochopit', že dôstojnost' l'udskej osoby je neodňatel'ná a nepopieratel'ná práve preto, lebo vo svojom nevyhnutnom, hoci často nespoznanom vzt'ahu k transcendencii, majú l’udské osoby transcendentný zdroj svojho bytia a tiež konečného určenia.

Kl’účové slová: Relačný personalizmus, l’udská osoba, antropológia, personalizmus, Kierkegaard, Tillich

\section{Introduction}

Our failure to actualize our human potential in living as persons (i.e., relational, authentic self) in personal relationships with others contributes to the movement of depersonalization, the end result of which is dehumanization and unfathomable destruction. The recent philosophical movement of personalism arises on the ashes of two horrible world wars and failed human ideologies (Nazism, Stalinist type of Bolshevism, imperialistic Capitalism), in which the Enlightenment's dream of necessary human progress was shattered to pieces with a threat to engulf all of the 
surviving human culture into nihilism. The move to personalism, however, does not appear to be as natural, self-evident, and satisfying in its results as we might wish. In recent times, the new sensitivity to the personal character of life has turned inward to self-interest, rather than outward to the concerns of global humanity. On the other hand, this needs not be a problem, as we see in the kind of personalism that builds on Thomas Aquinas' philosophical legacy and which helps us "identify the personalism rooted in the doctrine of St. Thomas and to separate, at the very outset, a social philosophy centered in the dignity of the human person from every social philosophy centered in the primacy of the individual and the private good." Such "Thomistic personalism stresses the metaphysical distinction between individuality and personality." (Maritain, 1966: 13) This paper argues that the "classical" personalist agenda of philosophers such as Emmanuel Mounier, Jacques Maritain (Dancak, 2014), and others need to be supported by a robust understanding of the relationality of the human person if it wants to avoid pitfalls of the bias toward elevating the capacity of rational thinking and self-determination as foundational for the dignity of human person. We also wish to propose that Kierkegaard's relational anthropology and "his strand of theological existentialism has been and may continue to be a valuable resource for developing the agape personalism in our striving to bring about an existential revolution on the inner-personal as well as inter-personal levels." (Valco, 2016: 97)

\section{Countering the Forces of Depersonalization}

As a modern philosophical movement, personalism developed in the $19^{\text {th }}$ century in reaction to what many had then considered depersonalizing traits in Hegelian idealism, Spinozean pantheism, and Enlightenment rationalism. In addition, it attempted to provide arguments against the Darwinian evolutionary determinism and Marxist collectivism in the Marxist political movement of the time. "In its various strains, personalism always underscores the centrality of the person as the primary focus of investigation for philosophical, theological, and humanistic studies. It is an approach or system of thought which regards or tends to regard the person as the ultimate explanatory, epistemological, ontological, and axiological principle of all reality..." (Williams and Bengtsson, 2016).

Personalism continues to be relevant today as the forces with which it originally took an issue continue to affect individuals and societies today (Kondrla - Repar, 2017; Hanes - De Muynck, 2017; Hajko, 2017). The phenomena of depersonalization show their detrimental effects primarily among the disadvantaged and marginalized individuals and groups in society. However, "even the economically and socially 'successful' individuals - who constitute a critical majority in most developed Western economies (especially in those of the social-democratic type, such as Germany) - are far from being beyond dangerous waters. They face the dangers of 'flattening' and manipulation. Human individuality and personhood seem to be lulled by the omnipresent slogans of freedom, especially in its economic and moral senses, only to be consumed and 'flattened' by the 'soft' totalitarian power of consumerism. The loss of authentic individuality (in Kierkegaard's sense) goes unnoticed in this process, as individuals are subconsciously influenced by the omnipresent normative images and messages of economic, political, and cultural marketing ads and media content. People are invited to celebrate their freedom of choice, ridden of the burdensome task of a true self-reflection. They are to devote their time and energy into solving 'practical issues' at hand and shy away from the 'impractical issues' of spiritual and moral integrity and deep moral responsibilities. These seemingly less tangible realities become less and less intelligible and increasingly perplexing, as individuals lose grip with the inner core of their being (their 'authentic selves'), which urges them, even more, to flee into the more 'intelligible' and 'real' world of economic choices and instantly available gratifications. Thus the vicious circle of 
economic realities intertwined with insatiable human desires and unquenchable fears closes in upon us." (Valco, 2015: 135) The forces of depersonalization and subsequent dehumanization, therefore, seem to be more at work today than a century ago (Turcan, 2017).

\section{Tillich's Concepts of Anxiety and Alienation}

The movement of depersonalization and our inadequate attempts to live as persons are closely related to three concrete manifestations of human alienation (alienation from themselves as persons but also from their ultimate ground of being), to use the terms of Tillich's (1965) phenomenological ontology:

$\begin{array}{llll}\text { 1. } & \text { Ontic Anxiety } & - & \text { threat of non-being } \\ \text { 2. } & \text { Spiritual Anxiety } & - & \text { threat of meaninglessness } \\ \text { 3. } & \text { Moral Anxiety } & - & \text { threat of guilt }\end{array}$

The notion of estrangement / alienation is important here. It has been commonplace for a whole series of philosophers and artists to describe the world as one of the fragments, a disrupted unity. This implies that individualization has become excessive (at the expense of participation) and has led to the loneliness of the human being before his fellow humans and before the 'Absolute' (ultimate ground of being conceived either philosophically, religiously, or ideologically). This, in turn, drives one into one's inner experience (as a safe haven) where one is still further isolated from the outside world (Pala, 2015). When put in religious terms: the presupposition of this tragic nature of human beings is their transcendent Fall, a condition of disconnectedness and alienation on both, the horizontal and vertical levels. We are able, in this condition, to develop and use our faculties of reason, emotion, and will, but our rationality in this 'alienated state' tends to be used to justify and attain the desires of a proud or despairing, but always hopelessly self-centered human heart. Rationality does not always develop into veracity (i.e., the desire of the moral subject to know and attain the truth) and the kind of freedom (Ambrozy, 2017) that we derive from our rational striving is divorced from the unity of Truth, Beauty and Goodness that we ultimately covet.

Sokolowski (2008) argued for the opposite when it came to the concept of 'veracity.' "Veracity is the human inclination to attain the truth of things... It is the impulse toward truth, not the virtue of truthfulness... Veracity means practically the same thing as rationality, but it brings out the aspect of desire that is present in rationality, and it has the advantage of implying that there is something morally good in the fulfillment of this desire. It also suggests that we are good and deserving of some recognition simply because we are rational [emphasis mine]. ... Failing to develop our veracity is not just one of the ways we can be unsuccessful as human beings; it is the way in which we fail and make ourselves false, that is, unreal as what we are." (Sokolowski, 2008: 21) Sokolowski combined Eros with rationality in his notion of veracity. "Veracity is the Eros involved with rationality. We are persons because we are rational, but our rationality is not merely a skill in finding things out; it also involves the desire to possess truth... It is in us because of what we are, not because we have chosen it. It would be incoherent to say that it arises as the outcome of a choice... We are made human by it, and it is there in us to be developed well or badly. Our exercises of it are indicated by the declarative use of the first-person pronoun." (Sokolowski, 2008: 21)

This is where we differ from Robert Sokolowski's (2000; 2008) more optimistic accounts of the phenomenology of the human person. If we borrow Paul Tillich's existential perspective, the ultimate concern of human life arises from the dialectic of good and evil that we experience. It is an intense inward experience of anxiety

XLinguae, Volume 11 Issue 1XL, January 2018, ISSN 1337-8384, eISSN 2453-711X 
(Pavlikova, 2017) and desire, doubt, and hope. Experiencing such ultimate concern, we are drawn from without to that which is beyond us, thus being opened to transcendence/Transcendence. The failure to acknowledge one's ultimate concern leads either to futile human utopias (social and political activism), a life of blind hedonism (experiential activism - pleasure, entertainment) or the despair of nihilism (passive despair). All of these three options fail to treat human beings as ends in themselves, thus falling short of establishing human dignity and inalienable rights as intrinsic to every human being as a person. Hence our failure to "have time for others" so that we might "give our time a transcendent meaning" (Klun, 2017: 12).

\section{Going beyond Phenomenological Personalism: Towards a relational understanding of the Human Person}

The term human person is a good starting point but needs more clarification. Should we define the human person based on his inner (intrinsic) qualities and capacities? If so, capacities of the psychosomatic unity of our bodily existence should we favor and which should we consider as less important: rational, emotional, intuitive, willing, self-awareness, memory (narrative identity) (Petkovsek, 2016), imaginative, relational (in terms of our capacity to communicate and enter into relationships) etc.? Attempts to identify the essence or constitutive elements of human personhood based on the human individual's innate capacities amount to helpful descriptions of human existence on the phenomenological level (Sokolowski 2000; 2008) but fail to provide the necessary foundation for human dignity and inalienable rights.

As one of the founding fathers of the personalist movement, Jacques Maritain is known for neo-Thomistic reasoning which can be summarized in the following way: "The human person is ordained directly to God as to its absolute ultimate end. ... This direct ordination of a human person to God transcends every created common good both the common good of the political society and the intrinsic common good of the universe. ... Thomism wants to make sure that the personal contact of all intellectual creatures with God, as well as their personal subordination to God, be in no way interrupted. ... Everything else - the whole universe and every social institution - must ultimately minister to this purpose; everything must foster and strengthen and protect the conversation of the soul, every soul, with God" (Maritain, 1966: 15-16). In addition, as Maritain observes, "[t]he notion of Divine Providence may be legitimately inferred from this principle: God is in control of the Universe, and things are happening under his providential rule with the aim to bring the human persons back into an intimate relationship with Him. In a way, we might say that this is why the universe continues to exist" (Maritain, 1966: 17) Humans are willed and governed for their own sakes and not as instruments for some external goals. On the other hand, are necessarily ordained to the perfection of the created whole. The important emphasis, however, is following: human beings may be the constitutive parts of the Universe, but the primary goal of [their] existence is to find joy in [their] relatedness to God. "The relatedness of human persons to the divine, Transcendent Whole, predisposes them to be related in the proper way to the common good of the Universe, that is, the created realm. ... In intellectual creatures alone, Aquinas teaches further, is found the image of God. ... the intellectual creature alone bears the image of God. Thus the human person alone is capable of grace. ... The notion of grace points us beyond the immanent frame of this world towards transcendence; this is so because the free act of the human person, considered in its pure and secret intimacy as a free act, is not of this world. By its liberty/freedom, the human person transcends the stars and all the world of nature" (Maritain, 1966: 18-20). Together with Thomas Aquinas, therefore, Maritain argues "that the good of grace of one person is worth more than the good of the whole universe of nature." (Maritain, 1966: 20) In the human heart/soul, we find the intersection of eternity and temporality. 
Another possibility is to ground the dignity of the human person on outer (extrinsic) conditions, endowments conferred by the immanent 'other' and/or the Transcendent Other. Human contingency points us to a transcendent source of both, our being (ontologically) and existence as persons (phenomenologically, ethically - as selfaware, moral persons). We are not necessary, self-constituted (and thus selfreferential) beings. Someone "willed us" into existence without our asking. This does not need to be understood in any mystical way, by the way. We may, as well, stay in the mundane dimension and remember that each of us has (had) biological parents who, so to speak, "willed us into existence." Thus, we are temporal, limited, conditioned, dependent, teleologically ordained beings. From the perspective of our 'horizontal contingency,' we find ourselves 'tossed into existence' by our parents (ontological aspect); imparted with the language, symbols, narratives, shared practices (both sacred and secular) of our parents and culture (spiritual aspect understood as vision and meaning of life); and shaped by examples and practices of moral nature (moral aspect; Ethos). From the perspective of our 'vertical contingency' (Transcendence understood beyond our biological and social contingencies), we yearn for a continuity of our being (longing for eternity; ontological aspect); we yearn for meaning and self-fulfillment in actualizing our potential, reaching for the unity of Truth and Beauty (spiritual aspect); and we year for a self-actualization in a life of virtue, reaching for the ideal of Goodness (moral aspect). Our being 'tossed into existence' as embodied beings is not a curse but a gift, an opportunity to actualize our human potential in developing our human personhood. Our contingencies imply, and our shared human experience confirms that we are essentially relational beings. As bio-psycho-social beings we are born with an intrinsic porosity - here we are referring to Charles Taylor's 'pores self' (2008), being able to receive with trust the selfcommunication of others (and/or the Transcendent Other).

Thus, the human person is fundamentally relational, even before one develops his capacity of self-awareness. My being as the being of a human person is a gift of love relationships (my parents, grandparents, etc.). Before I was born, a psycho-biological connection was established between my mother and me. I was born out of a relationship of love into relationships of love within my family. The intimate other's relation to me (my mother's) is constitutive to my self (my emerging personhood) - I derive my sense of security and belonging through an elementary relationship of trust (faith) that is developing between my mother and I. Some developmental psychologists call this psychological imprinting, which is similar to and yet much more complex than the merely instinctive imprinting in birds. Before being fully aware of my self, before the thinking, feeling, willing 'I,' there is a trusting 'I' - a sense of elementary security and belonging of the emerging self, enabled by a fundamental porosity of my being. This trusting I is established by the relationship of the intimate other (mother) to me. This initial and continuous relatedness of the other to me is a fundamental endowment that helps me become who I am as a person. My self thus emerges as a result of others' selves relating to me and my reciprocal relating to them. Before I was conceived, my coming into being was intended by someone (my parents). Even if conceived unintentionally, I am still part of a circle of love that desires life and thrives in mutually caring relationships by virtue of my belonging to the human species as a fellowship of persons. I become a person because other persons love me, care for me, self-communicate themselves to me, and imagine a future actualization of my personhood. There is a web of relationships that sustains me (providing care, symbols, language, stories, rituals) before I reach self-awareness.

\section{The constitutiveness of transcendence for the human person}

We are thus called to and defined by a movement of inner and outer transcendence, thus recovering a sense of transcendent relationality of the human person (Zalec, 
2011). We recognize ourselves as free and responsible agents. Inner transcendence is the (horizontal) movement of the 'relational I' in which I recognize and enact my responsibility to others. I employ my rational, intuitive, emotional, imaginative/artistic, and volitional capacities as I relate to others. I derive my dignity and respect as a human person from my participation in the personal web of relationships, being necessarily related not merely to my parents but indirectly to the emerging and ever-renewing community of human persons (Kardis, 2006). In it, I am necessarily situated (most of the time also recognized) as an embodied member of a moral community (Bravena, 2010: 25). Outer transcendence is the (vertical) movement of the 'relational I,' invited, and made possible by what I imagine or experience as 'the divine,' in which I recognize my relatedness to, desire for, and dependence on the divine Other. An internalized notion and experience of $\mathrm{t}(\mathrm{T})$ ranscendence provides us with inspiration and aspirations by which all life has its meaning, stimulus, and orientation (McLean, 2010). In a context of such 'reconciled relationality,' my thinking, feeling, and willing is being purified and recalibrated towards that which is true, good, and beautiful. My rationality manifests itself as veracity, opening my self to freely wish for that which is good not only for me but also other living persons occupying this living planet.

In his relational, transcendent personalism, the Eastern Orthodox metropolitan of Pergamon, John Ziziolas, attempts to transcend the anthropological existentialist perspective of Emmanuel Levinas (1999) by filling it with a more positive conception, especially when it comes to the related question of the ontology of virtue. The radicalization of the other in Levinas paralyzes us to some extent. Levinas wants to remain a Jew; there is no communion, no constitutive relationship within God. He is and remains the absolute Other, but a "static Other." We might argue that Buber (1970) has a way of breaking out of Levinas' impasse. Philosophical clarification moves forward when it is willing to engage texts that are mythical/religious (nondiscursive), but philosophy must learn to engage them imaginatively! We must move beyond propositional metaphysics. The experience of transcendence may be a mutual, common basis for an imaginative discourse across philosophies and cultural narratives. This is where the Eastern Orthodox thinker, John Zizioulas, may serve us as an inspiration. Reading Zizioulas' text requires an exercise of imagination and trust on the side of the reader. Otherwise, it is incommunicable to readers from other backgrounds, even to Christians without a certain mystical experience of the love of the OTHER. Elaborating on the legacy of Maximus Confessor, Zizioulas maintains that nature (including the human "embodiment") must be understood in a positive sense. He comes with the term "logos physeos" - telos of nature - nature exists in the hypostasis of the Logos; it means that nature is so ordered that it complies with the will of its Creator. He also points out the fact that Eastern fathers (Irenaeus, Athanasius, etc.) distinguished between "image" and "likeness" in their theological anthropologies. We are born in the image of God but must grow in His likeness.

God is a community of love (agape) - this community of love defines me as a human person, gives me my identity, helps me experience my self uniquely as the self-giving self in love for the other. The other is taken not only as nature (as a WHAT) but as a person (a WHO), a particular being. Otherness is conceived of as uniqueness (on the level of personhood), rather than as difference (natural, or moral category). The anthropological question "who am I", according to Zizioulas, must be answered in a narrative fashion, while remembering the limitedness of being and its contingency, as well as its uniqueness, unrepeatability. The self is not self-sufficient, self-referential, absolutely free in its autonomy. Instead, we should consider the principle of personal causation of being. Also, if we define love in ontological terms, love must replace the ontological role of being (ousia). Thus, according to Zizioulas, "what matters ontologically is not 'what' one is but the very fact that he or she is and is not someone else. The tendency of the Greek Fathers to avoid giving any positive 
content to the hypostasis of the Trinity, by insisting that the Father is simply not the Son or the Spirit, and the Son means simply not the Father and so on, points to the true ontology of hypostasis: that someone simply is and is himself or herself and not someone else, and this is sufficient to identify him or her as a being in the true sense." (Zizioulas, 2006: 111) This concept (or rather, this perspective) is foundational for Zizioulas: "This point acquires tremendous existential significance when placed in the context of ordinary human life. In relationships of genuine love, which are the proper context for the 'experience' of an ontology of personhood, one does not - and should not - identify the other with the help of their qualities (physical, social, moral, etc., i.e. in terms of WHAT), thus rejecting or accepting the other on that basis as a unique and irreplaceable partner in a relationship that matters ontologically", (Zizioulas, 2006: 111) on which one's own personal identity depends, i.e. in terms of WHO.

Being inspired by such anthropological understanding, we may argue that the trusting $I$ is (and ought to be!) situated in love relationships in a redeemed/reconciled community of persons who live in (and from) forgiveness and cultivate a mutual sense of reconciliation and belonging. This shared experience opens up new possibilities of freedom to be there for the other. (Sturak, 2016: 46-47) This process can be conceived of on the level of horizontal transcendence but is more fully realized when the porosity of human persons freely receives the gift of participation in the relationship with outer Transcendence by faith as a complex inner disposition of the moral subject. This way of existence seems arguably superior to that of the "buffered self,' as Charles Taylor observes: "For the modern, buffered self, the possibility exists of taking a distance from, disengaging from everything outside the mind. My ultimate purposes are those which arise within me, the crucial meanings of things are those defined in my responses to them.... By definition for the porous self, the source of its most powerful and important emotions are outside the 'mind'; or better put, the very notion that there is a clear boundary, allowing us to define an inner base area, grounded in which we can disengage from the rest, has no sense. ...the boundary between self and other is fuzzy, porous. And this has to be seen as a fact of experience, not a matter of 'theory,' or 'belief.' (Taylor, 2007: 38-39)

\section{Conclusion: A 'Kierkegaardian' relational personalism?}

We argue that the way to a genuine, fulfilling, and lasting sense of contentment may lead through the perils of one's personal 'existential revolution,' which will be connected not just with a developed notion about but also the experience of inner and outer transcendence. Charles Taylor, perhaps unwittingly, follows in and builds upon the legacy of Kierkegaard's transcendent relational anthropology. To facilitate such 'existential revolution,' according to Taylor, will require a potent critical reflection on the widely present phenomenon of what he calls the "immanent frame." "...we can see in the naturalistic rejection of the transcendent that I have been describing the ethical outlook which pushes to closure. Now while many have felt a sense of unease within the modern order with its disciplines and instrumental reason, and have been driven towards an opening to the transcendent, there is also a set of ways in which we can feel comfortable and empowered within this order. [...] The buffered self-feels invulnerable before the world of spirits and magic forces, which still can haunt us in our dreams, particularly those of childhood. Objectification of the world gives a sense of power, and control, which is intensified by every victory of instrumental reason. [...] We can come to see the growth of civilization, or modernity, as synonymous with the laying out of a closed immanent frame; within this civilized values develop, and a single-minded focus on the human good, aided by the fuller and fuller use of scientific reason, permits the greatest flourishing possible of human beings. [...] What emerges from all this is that we can either see the transcendent as a threat, a dangerous temptation, a distraction, or an obstacle to our greatest good." (Taylor,

XLinguae, Volume 11 Issue 1XL, January 2018, ISSN 1337-8384, eISSN 2453-711X 
2007: 548) Having spent most of his recent academic career trying to define the nature of the modern self and the secular age we live in, Taylor identified several elements (or strands) and sources of the modern identity. "A distinctly modern conception of selfhood thus encompasses a being who values freedom, who possesses inner depths that are deserving of exploration, who sees nature as a source of goodness and contact with it as renewing, who prizes authenticity and individuality, who affirms ordinary life, and who feels the pull of benevolence toward the suffering of others." (Abbey, 2017: https://www.britannica.com/biography/Charles-Taylor) Taylor realizes that the difficulties the word "transcendent" poses for an intelligible discourse today are rather serious: "I fully recognize that a word like 'transcendent' is very slippery - partly because, as I hinted just now, these distinctions have been constructed or redefined in the very process of modernity and secularization. But I believe that in all its vagueness, it can serve in our context." He thus proposes an additional way of distinguishing between that which is immanent and the transcendent: "Another way of getting at something like the issue raised above in terms of within/without is to ask: does the highest, the best life involve our seeking, or acknowledging, or serving a good which is beyond, in the sense of independent of human flourishing? In which case, the highest, most real, authentic or adequate human flourishing could include our aiming (also) in our range of final goals at something other than human flourishing." (Taylor, 2007: 16)

The question of a relational identity of the human person, which not only touches on but rather is constituted by transcendence, is a foundational one for a competent and complex understanding of anthropology.

To be able to begin coping with the pressing question of 'existential revolution,' one needs to first deal with the fundamental question of Anthropology (Petro, 2006): What is a human being? What constitutes the human individual? How do we bring together the psychosomatic, intuitive, passionate, social, cultural, spiritual (etc.) dimensions of his/her existence? The above-described notion of the human person is merely an interpretative model that is to be employed to help us in our search for human mutuality. Hence we continue to ask ourselves questions, such as: What do we have in common as humans, regardless our metanarratives? How do we share in the phenomenon of Personality when we have different religions/cultures? We share in the phenomenon of personality essentially and existentially when we start asking questions of transcendence (immediate and ultimate). We need to aspire for a life of transcendence, going beyond our immediate needs, earthly loves, actual impulse.

The human self is actualizing his/her personality in his/her longing for selftranscendence and ultimately (though often unwittingly) for Personal Transcendence. We are speaking here of transcending the bio-psycho-social determination of human temporal life.

We propose the approach of a "relational personalism" described above as the best model for establishing a firm foundation for the undeniable and dignity of every human person. Moreover, relational personalism seems to provide positive implications for human interactions on all levels of human experience. We agree with Igor Bahovec's emphases on "the importance of genuine dialogue, the importance of the principle of person and the process of personalisation, fraternity, reflection and discernment, relationship ethics, and of memory and wisdom" and consider these as part of a creative theistic (Christian) personalism's response to "destructive nihilism and immanent narcissism" that plague our societies. (Bahovec, 2015: 335)

Building on the tradition of a transcendent religious and moral anthropology, Kierkegaard could possibly serve as a resource and critical inspiration in our contemporary attempts to answer this question (Kralik - Tinley, 2017). He may be considered as a precursor of precisely the kind of 'relational personalism' that we talked about earlier. What we find in [him] is a deliberate "focus on the individual as a responsible subject before [the Transcendent Other]", which directly ensues from 
[his] conceiving of cultural and religious narratives "as "existence-communication"" (Valcova, 2014: 287), rather than mere set of doctrinal formulations. In his masterpiece the Sickness unto Death, Kierkegaard provides a relational account of the self, thus offering a groundbreaking anthropological perspective which we might label 'transcendent anthropology.' In opposition to the arid intellectualism of Hegelianism, Kierkegaard invites his readers "to venture wholly to become oneself, an individual human being, this specific individual human being, alone before God, alone in this prodigious strenuousness and this prodigious responsibility" (Kierkegaard, 1980: 5). He conceives the human self-being constituted in the very act of relating to itself (in an act of intentional self-awareness) and, subsequently, relating its own relatedness i.e., one's conscious critical self-awareness, - to a transcendent source of one's being (in Kierkegaard's case this transcendent source was a personal deity, but we may think of it in more general, philosophical and moral categories). The human person is thus born out of a constitutive relation to the transcendent Other (Valco, 2016: 101), not just an immanent other, according to Kierkegaard: "in relating itself to itself and is willing to be itself, the self rests transparently in the power that established it..." (Kierkegaard, 1980: 49) Switching to a more explicitly theological language based on the Christian monotheistic metanarrative of reality, Kierkegaard speaks of the emerging, relational "self" of the human person that emerges within a relationship of trust with the divine Other: "A self directly before Christ is a self-intensified by the inordinate concession from God, intensified by the inordinate accent that falls upon it because God allowed himself to be born, become man, suffer, and also die for the sake of this self. As stated previously, the greater the conception of God, the more self; so it holds true here: the greater the conception of Christ, the more self." (Kierkegaard, 1980: 113-114) Rather than speaking of a 'given,' or authentic static self, Kierkegaard talks about a 'becoming' or an 'emerging' self. This Kierkegaardian emphasis on calling the human self to what we may call 'relational authenticity' on both plains of existence - the immanent and the transcendent - "may constitute the much-needed inception (or inculcation) that will then grow to fuller complexity and beauty of transformed individuals and societies." (Valco, 2015: 137) For this to happen, however, we will need to recover and critically re-appropriate the power of constitutive narratives (religious and secular), embodied in human communities that are united around a shared vision of life and ethos stemming from the given narrative.

\section{Bibliographic References}

ABBEY, R. 2017. Charles Taylor. In: Encyclopedia Britannica [online]. Encyclopedia Britannica Inc. Available online: https://www.britannica.com/biography/ CharlesTaylor

AMBROZY, M. - KRALIK, R. - MARTIN, J.G. 2017. Determinism vs. freedom: Some ethics-social implications | [Determinismo vs. libertad: Algunas implicaciones etico-sociales] . In: XLinguae vol. 10, n. 4, pp. 48-57. ISSN 1337-8384.

AMBROZY, M. - KRALIK, R. - POYNER, J. 2018. The issue of periodization in Wittgenstein's philosophy of religion. In: European Journal of Science and Theology, vol. 14, n. 1, pp. 115-124. ISSN 1841-0464.

BAHOVEC, I. 2015. Christianity in confrontation with individualism and crisis of western culture: person, community, dialog, reflexivity, and relationship ethics. In: Bogoslovni Vestnik, vol. 75, n. 2, pp. 335-346.

BRAVENA, N. 2010. Jezis kristus, bratr a blizni jednaji na mem miste. Zastupnost v teologii Dietricha Bonhoeffera. Praha: HTF KU. ISBN 978-80-87127-23-0.

BUBER, M. 1970. I and thou. W. Kaufmann (trans.). New York: Scribner.

XLinguae, Volume 11 Issue 1XL, January 2018, ISSN 1337-8384, eISSN 2453-711X 
DANCAK, P. 2014. The personalist view of the education in the philosophy of $\mathbf{J}$. Maritain. In: Studia Theologica Babes Bolyai Studia Catholica, vol. 59, n. 1-2, pp. 133-142.

HAJKO. 2017. Ethics and Science: Challenges and Possibilities. In: Komunikacie, vol. 19, n. 1, pp. 64-68. ISSN 1335-4205.

HANES, P. - DE MUYNCK, B. Deification of Technology and the Dignity of the Human Person. In: Komunikacie, vol. 19, n. 1, pp. 121-125. ISSN 1335-4205.

Kierkegaard, S. 1980. The Sickness unto Death. H. V. Hong and E. H. Hong (trans.). Princeton, Princeton University Press.

KARDIS, K. 2006. Jan Pavol II. a moralne zaklady Europy. In: Dancak, P. (ed.): Sapiencialny charakter antropologie Jana Pavla II. v kontexte európskej integrácie. Presov : PU v Presove GTF, pp. 254-267. ISBN 80-8268-571-1.

KIERKEGAARD, S. 1980. The Sickness unto Death. Princeton: Princeton University Press.

KLUN, B. 2017. Modern Technology's Effort to Master Time as a Challenge for Ethics. In: Komunikacie, vol. 19, n. 1, pp. 9-13. ISSN 1335-4205.

KONDRLA, P. - REPAR, R. 2017. Ontological Consequences of the Ethics of Technology. In: Komunikacie, vol. 19, n. 1, pp. 19-24. ISSN 1335-4205.

KRALIK, R. Søren Kierkegaard's influence on the thinking of Karol Nandrásky. In: European Journal of Science and Theology, vol. 13, n. 1, pp. 25-34. ISSN 1841-0464.

KRALIK, R. - TINLEY, S. J. 2017. Kierkegaard's Ethics as an Answer to Human Alienation in Technocratic Society. In: Komunikacie, vol. 19, n. 1, pp. 25-29. ISSN 1335-4205.

LEVINAS, E. 1999. Alterity and transcendence. Columbia: Columbia University Press.

MARITAIN, J., 1966. The person and the common good. New York: Charles Scribner's Sons.

MCLEAN, G. F. 2010. Religion and culture. Washington D.C..: Center for research in values and philosophy.

PALA, G. 2015. The Family in Media Ciphers. In: European Journal of Science and Theology, vol. 11, n. 6, p. 45-56. ISSN 1841-0464.

PAVLIKOVA, M. 2017. Consciousness of Anxiety in Literary Work of Don DeLillo. In: XLinguae Journal, Vol. 10, n. 1, p. 62-69, ISSN 1337-8384.

PETKOVSEK, R. 2016. Spomin kot obljuba: pogled z vidika mimetične teorije in hermenevtike eksistence. In: Bogoslovni Vestnik, vol. 76, n. 3/4, pp. 495-508.

PETRO, M. 2006. Clovek ako osoba - nadej pre Europu. In: Dancak, P. (ed.): Sapiencialny charakter antropologie Jana Pavla II. v kontexte európskej integrácie. Presov : PU v Presove GTF, pp. 96-111. ISBN 80-8268-571-1.

SOKOLOWSKI, R. 2000. Introduction to phenomenology. Cambridge: Cambridge university press.

SOKOLOWSKI, R. 2008. Phenomenology of the human person. Cambridge: Cambridge university press.

STURAK, P. The legacy of the Greek Catholic leading personalities and martyrs in Slovakia and their contribution for the building up of a free Slovak society. In: European Journal of Science and Theology, vol.12, N. 4, pp. 39-48.

TAYLOR, C. 2008. Buffered and porous selves. Comment on the secular age [online]. In: Antwerpen, J. (ed.). At the immanent frame. Social science research council blog. Available online: http://www. Ssrc. Org/blogs/immanent_frame

TAYLOR, C. 2007. A Secular Age. Cambridge Massachusetts - London, UK: Harvard University Press.

TILLICH, P. 1965. Ultimate concern. New York: Harper \& Row.

TURCAN, C. 2017. Hans Jonas' Ethics of Technology: Risks of Technological Society. In: Komunikacie, vol. 19, n. 1, pp. 35-38. ISSN 1335-4205. 
VALCO, M. 2015. Rethinking the role of Kierkegaard's "authentic individual" in liberal capitalist democracies today. In: European Journal of Science and Theology, vol. 11, n. 5, p. 129-139. ISSN 1841-0464.

VALCO, M. 2016. . In: European Journal of Science and Theology, vol. 12, n. 1, pp. 97-105. ISSN 1841-0464.

VALCOVA, K. 2014. Povaha a kontext krestanskej viery v post-krestanskom svete: Kriticka apropriacia Kierkegaardovho posolstva. In: Acta Kierkegaardiana supplement (Kierkegaard and Existential Turn), vol. 4 (2014). Toronto: Kierkegaard Circle, pp. 284-296.

WILLIAMS, T. D. - BENGTSSON, J. O. 2016. Personalism. In: Edward Zalta (ed.). The Stanford encyclopedia of philosophy (summer 2016 edition) Available online: https://plato.stanford.edu/archives/sum2016/entries/personalism/.

ZALEC, B. 2011. On Not Knowing Who We Are: The Ethical Importance of Transcendent Anthropology. In: Synthesis Philosophica, vol. 51, n. 1, pp. 105-115.

ZIZIOULAS, J. 2006. Communion and Otherness: Further Studies in Personhood and the Church. London: T\&T Clark. ISBN 9780567031471.

Words: 6301

Characters: 41245 (22,91 standard pages)

doc. PhDr. Michal Valco, PhD.

Department of General and Applied Ethics

Faculty of Arts

Constantine the Philosopher University in Nitra

Hodzova 1, 94901 Nitra

Slovak Republic

mvalco@ukf.sk

Mons. Prof. ThDr. Peter Šturák, PhD.

Greek Catholic Theological Faculty

University of Presov in Presov

Ul. Biskupa Gojdica 2

08001 Presov

Slovak Republic

peter.sturak@unipo.sk

XLinguae, Volume 11 Issue 1XL, January 2018, ISSN 1337-8384, eISSN 2453-711X 